\title{
FEMINISME DALAM MAJALAH PEREMPUAN
}

\author{
Helen Diana Vida \\ helendianavida@gmail.com
}

\begin{abstract}
Mass media, as agents of culture, reflects the general condition of society. Among the existing mass media, there are some that are closely linked to specific segments, for example, women's magazines. Women's magazines in Indonesian contains the value of feminism and give affect to Indonesian women's, they requires not only equality in gender but also independence in their live.
\end{abstract}

Keywords : Women Magazine, Feminism

\section{PENDAHULUAN}

Tuhan menciptakan laki-laki dan perempuan untuk saling melengkapi satu sama lain. Dilihat dari konsep gender, perempuan sering digambarkan lemahlembut, emosional atau keibuan. Sedangkan laki-laki dianggap kuat, rasional, jantan dan perkasa (Fakih, 2006: 8). Gender mengisyaratkan bahwa kategori lakilaki dan perempuan merupakan konstruksi sosial yang membentuk identitas lakilaki dan perempuan (Ibrahim, 1998: xxvi).

Ide tentang perempuan yang menyatakan secara kodrat lebih lemah jika dibandingkan dengan laki-laki, sejak awal memang sudah dikonsepsikan, disosialisasikan, diinternalisasikan, dan bahkan terus-menerus dipertahankan, tidak saja oleh masyarakat awam, tetapi juga oleh sebagian besar ahli filsafat. Seperti Aristoteles menulis bahwa perempuan adalah laki-laki yang tidak lengkap, sedangkan Schopenhauer menggambarkan perempuan sebagai ras rendah, berbahu sempit, pinggul lebar, kaki pendek, kekanak-kanakan, sembrono dan berpikiran pendek (Kasiyan, 2008: 34).

Ehrlich seperti yang dikutip oleh Ollenburger \& Helen (2002:1), menulis bahwa dalam sosiologi, perempuan banyak diabaikan sebagai suatu objek studi. Hanya di bidang perkawinan dan keluarga ia dilihat keberadaannya. Kedudukannya dalam sosiologi, dengan kata lain bersifat tradisional sebagaimana ditugaskan kepadanya oleh masyarakat yang lebih besar, bahwa tempat kaum perempuan adalah di rumah. Suhardiman dalam Verdiansyah (2007: 4) mengatakan bahwa perempuan sebagai mitra laki-laki harus mampu mewujudkan tiga peran sekaligus, yakni sebagai Ibu, sahabat dan kekasih bagi pria, baik dalam lingkungan keluarga maupun profesi dan sosial kemasyarakatan. Peran demikian merupakan citra perempuan Indonesia secara tradisional. Perempuan tidak mungkin lagi hanya mendasarkan diri pada paham-paham klasik, yang 
memungkinkan masyarakat menerima begitu saja kegiatan perempuan karena kewanitaannya. Masyarakat kini berkembang lebih rasional, sehingga memilih mana yang berguna dan mana yang tidak. Penguasaan profesi juga akan mengubah pandangan masyarakat terhadap perempuan. Jika kaum perempuan mampu menunjukkan profesionalisme, anggapan masyarakat mengenai lemahnya perempuan akan terhapus secara bertahap.

Menurut Hardjana et al (1998: 91), berdasarkan sifatnya yang kemudian dikonstruksi secara sosial, perempuan seringkali tidak menyadari potensi apa saja dalam dirinya yang dapat dikembangkan. Dalam masyarakat tradisional agraris di pedesaan, misalnya kesadaran perempuan terpusat pada "Pengabdian diri pada keluarga" (family devotion). Sebaliknya dalam masyarakat modern - industrial perkotaan, fokus kesadaran perempuan terletak pada "Perwujudan cita-cita" (self actualization) sesuai dengan martabatnya. Maka nilai yang mendasari kerja kerasnya adalah demi pengembangan martabat / personal growth.

Ibrahim (2009: 41) mengatakan bahwa seseorang disebut modern bila ia lebih mengutamakan sikap rasional, efisien, praktis, mandiri, serta meninggalkan hal-hal yang bersifat mitos, takhayul, serta tabu yang tidak bisa dijelaskan secara rasional. Dalam konsep modern, laki-laki dan perempuan tidak lagi dibedakan, kecuali dalam hal yang bersifat kodrati. Pada dasarnya perbedaan hakiki antara perempuan dan laki-laki hanyalah bahwa perempuan bisa hamil, melahirkan dan menyusui; sementara laki-laki tidak. Hal-hal yang selama ini dianggap sebagai stereotipe atau karakteristik laki-laki dan perempuan, sebenarnya hanyalah bentukan pola asuh serta budaya, baik dalam keluarga maupun masyarakat.

Dalam perkembangannya, kehidupan kaum perempuan mulai mengalami perubahan. Pada Abad ke - 18, di Prancis muncul gerakan perempuan yang didorong oleh ideologi pencerahan (Aufklarung), yang menyatakan manusia diberi kesempatan mencari kebenaran dengan menggunakan akal, oleh sebab itu laki-laki dan yang merupakan mahluk rasional sama-sama berhak untuk mencari kebenaran melalui pendidikan (Djarkasi, 2008: 119). Di dunia Barat, terutama Amerika, gerakan perempuan muncul pada tahun 1848 dalam konvensi di Seneca dan dianggap sebagai awal gerakan perempuan secara terorganisir (Djajanegara, 2003: 1). Gerakan perempuan di Jepang dimulai abad ke - 19 yang menuntut persamaan hak dalam keluarga dan masyarakat (Djarkasi, 2008: 119). Di Indonesia gerakan perempuan terjadi sekitar abad ke - 20 pada era R.A. Kartini. Pada masa tersebut, sebagian besar kehidupan perempuan berputar di kehidupan rumah tangga. Tujuan perempuan, seakan-akan hanya menikah dan membentuk keluarga. Sesudah menikah, hampir seluruh kehidupan perempuan di dalam rumah tangga. Dalam keadaan seperti ini, perempuan jadi tergantung pada lakilaki secara ekonomi, karena pekerjaan yang dilakukan di rumah tangga tidak menghasilkan gaji (Kasiyan, 2008: 58).

Seiring perkembangan jaman, perempuan mulai bisa memasuki dunia pendidikan dan bekerja layaknya laki-laki. Namun demikian tetap terjadi diskriminasi pada pembagian kerja antara laki-laki dan perempuan. Hanya dalam 
masyarakat industrial yang berkembang, pria dan wanita bersaing memperebutkan lowongan kerja yang sama, bangku sekolah, kekuasaan yang sama dan upah yang sama (Heryanto, 1998: 39). Perempuan dalam sistem pembagian kerja secara seksual, cenderung selalu di tempatkan dalam wilayah domestik atau rumah tangga, dengan serangkaian kerja yang sifatnya reproduktif seperti melahirkan, mengurus anak serta mengurus rumah tangga. Pada sisi lain, karena laki-laki menyandang serangkaian stereotip maskulinitasnya, yang seringkali selalu berkonotasi positif, maka laki-laki menempati posisi di wilayah publik yang sifatnya produktif seperti bekerja dan menghasilkan uang (Kasiyan, 2008: 55). Hal ini juga diakui oleh Lie (2005:21), yang menulis bahwa pembagian pekerjaan pun dilakukan bukan karena alasan efektivitas dan efesiensi demi tercapainya tujuan bersama antara laki-laki dan perempuan, melainkan karena perempuan dianggap tidak mampu, bodoh, dan tidak cakap untuk memikirkan hal lain diluar pekerjaan rumah tangga.

Perjuangan perempuan dalam meraih persamaan hak dengan kaum lakilaki, secara tidak langsung mengubah cara pandang perempuan terhadap hubungan romantika. Seiring munculnya kesadaran perempuan terhadap perwujudan cita-cita, maka menikah dan mengasuh anak bukan lagi tujuan utama dalam kehidupan mereka. Hal ini dapat dilihat dari semakin banyaknya kaum perempuan menikah dalam usia yang tergolong tua (Kartika, 2002: 61).

Menurut Dwiputri (2008: 31)1, beberapa dasawarsa terakhir ini, di kotakota besar makin banyak orang melajang sampai usia tinggi, uang lebih dianggap bisa membuat hidup lebih baik, bukan lagi pasangan hidup sehingga menikah bukan lagi prioritas utama bila penghasilan seseorang belum memadai. Hal ini juga diakui oleh Naqiyah (2005: 9), di desa masih terjadi pernikahan di bawah usia 19 tahun, sedangkan di kota laki-laki dan perempuan mulai menunda pernikahan dengan berbagai alasan diantaranya ingin melanjutkan studi, mengejar karier, dan lain-lain. Berdasarkan survey yang diadakan majalah Femina terhadap 100 perempuan Indonesia kelas menengah di perkotaan, diketahui bahwa sudah terjadi perubahan dalam sikap, pola pikir dan cita-cita sebagian perempuan Indonesia menjadi lebih modern. Tingkat pendidikan yang makin tinggi, globalisasi, isu kesetaraan dan arus informasi yang semakin terbuka, ikut mempengaruhi perubahan tersebut. Sebanyak 58\% responden mengaku tidak khawatir hidup melajang. Namun sebagian besar lajang di Indonesia sebetulnya masih mendambakan pernikahan (Savitri, 2009: 42). Tidak sedikit perempuan di perkotaan yang belum menikah pada usia tua, berpendapat bahwa mereka berusaha memberikan pengertian kepada lingkungan mengapa mereka belum juga menikah. Alasannya antara lain, pernikahannya berakhir dengan perceraian atau takut suami tidak setia (Kartika, 2002: 61).

${ }^{1}$ Agustine Dwiputri adalah salah satu pengasuh rubrik Psikologi di Harian Kompas 
Modernitas memang telah menimbulkan pergeseran nilai-nilai masyarakat, termasuk dalam hal penentuan pasangan hidup. Kondisi ini tampaknya didorong oleh semakin terbukanya akses bagi perempuan untuk mengenyam pendidikan sebagaimana kaum laki-laki. Pada gilirannya, ini mengakibatkan mundurnya usia perkawinan, baik pada laki-laki maupun perempuan. Jika pada masa lalu, perempuan yang telah mengalami menstruasi mendapat tekanan dari masyarakatnya untuk segera mengakhiri masa lajangnya, maka dewasa ini, khususnya di perkotaan, tekanan itu mulai melemah, bahkan sama sekali kendur. Usia yang bertambah, pendidikan yang baik, dan akses pada kegiatan ekonomi menjadikan perempuan lebih percaya diri untuk memilih sendiri pasangan hidupnya (Jamhari, 2003: 158).

Perubahan pola hidup perempuan saat ini tidak hanya di temui di Indonesia. Dalam diskusi yang dilakukan di Jakarta dalam rangka memperingati festival Hina Matsuri (Doa untuk anak perempuan), Michiko Maeyama², mengatakan bahwa perempuan Jepang selalu dihadapkan pada pilihan sulit ketika dewasa, yaitu antara menikah dan berkarier. Kedua pilihan ini sangat sulit diraih karena ketika memutuskan untuk menikah maka mereka harus mengurus anak dan keluarga sehingga tidak ada waktu dan tenaga untuk berkarier. Namun saat ini di Jepang terdapat fenomena semakin rendahnya angka kelahiran. Penyebabnya adalah perempuan lebih memilih berkarier di luar rumah. Perempuan Jepang saat ini banyak yang belum menikah hingga usia lebih dari 30 tahun. Bersamaan dengan itu, pria Jepang banyak yang enggan menikah, sehingga sulit bagi perempuan mencari pacar. Fatimah (2009: 47) mengakui bahwa perempuan Indonesia sudah mulai bergeser paradigmanya dalam melihat pernikahan. Saat ini bukanlah hal yang aneh bila seorang perempuan tidak terburu-buru menikah jika belum menemukan calon suami yang setara dan perempuan Indonesia masa kini telah menemukan eksistensi dirinya dalam pekerjaan.

Perempuan tidak lagi melihat tujuan hidupnya hanya sebatas menikah dan membentuk keluarga. Hal ini menunjukkan telah terjadinya pergeseran nilai, dimana pada awalnya perempuan menganut nilai pengabdian diri kepada keluarga, namun saat ini perempuan menganut nilai pengembangan diri dan martabat (Hardjana, 1998:91). Pergeseran nilai tersebut melibatkan media massa, karena hubungan antara perempuan dan media massa dalam masyarakat industri cukup erat. Media massa sendiri terdiri dari media cetak (seperti surat kabar dan majalah) dan media elektronik (seperti radio, televisi, film dan internet), media tersebut menjangkau orang dalam kelompok-kelompok, seperti media khusus pria, perempuan, dewasa, anak-anak, dan lain-lain (Berger, 2000: 113).

\footnotetext{
${ }^{2}$ Michiko Maeyama adalah Pemimpin Redaksi Sarasa, majalah untuk komunitas Jepang di Jakarta
} 
Dengan adanya berbagai jenis media massa dan juga pengelompokkan media berdasarkan penggunaannya, serta keterikatan masyarakat terhadap media, maka media menjadi suatu kebutuhan yang tidak dapat dilepaskan dari masyarakat. Hal ini ditegaskan oleh Armando (2004: 26), bahwa:

Kebutuhan akan media massa menjadi bagian dari gaya hidup masyarakat saat ini. Media massa dikatakan sebagai agen budaya yang sangat berpengaruh karena masyarakat modern mengonsumsi media dalam jumlah dan intensitas yang tak dapat dibandingkan dengan masa-masa sebelumnya. Media massa memang bukan merupakan sarana satu-satunya untuk berkomunikasi, namun demikian posisinya telah menjadi semakin sentral dalam sebuah masyarakat yang para anggotanya sudah semakin kurang berinteraksi secara langsung satu sama lain. Media massa hadir praktis dalam kehidupan masyarakat.

Media massa sebagai agen budaya secara tidak langsung mencerminkan kondisi masyarakat secara umum, hal tersebut menyebabkan masyarakat sangat bergantungan pada media untuk mendapatkan informasi, tak terkecuali dalam kaitannya dengan kehidupan perempuan. Hal ini terlihat dari masuknya topik perempuan dan media dalam salah satu dari 12 isu kritis Beijing Platform for Action tahun 1995, yang berdasarkan pada konsep bahwa media dapat memberikan kontribusi yang sangat besar dalam pemberdayaan dan kemajuan perempuan (Dwi, 2008: 521). Namun seringkali dalam pemberitaan media yang berkaitan dengan perempuan, tampilan dari media massa tersebut memiliki kecenderungan represif yang menempatkan perempuan lebih banyak pada peran reproduktif (di sektor domestik) dibandingkan dengan peran gender produktif (di sektor publik) tersebut disebabkan oleh demikian dominan nilai-nilai budaya patriarki (ideologi patriarki) dalam kehidupan kita (Sunarto, 2000: 5).

Peran media dalam perjuangan perempuan tidak sebatas pada persamaan hak dan pendidikan yang layak, namun juga memuat kehidupan perempuan yang berjuang dalam menentukan sikap dan mengatur hidupnya sendiri tak terkecuali masalah kehidupan romantika dan pernikahan. Contohnya saat ini iklan-iklan di majalah, televisi, sinetron, film layar lebar, dan video klip, banyak yang merepresentasikan perempuan lajang yang memiliki otonomi dan kekuasaan dalam dirinya. Industri media dan budaya popular telah menciptakan ledakan image perempuan lajang sebagai "orang Indonesia modern". Dalam proses ini, konsumerisme menjadi situs sementara di mana makna femininitas tentang perempuan lajang ditampilkan dalam berbagai gaya dan realisasi (Sushartami, 2002: 37). Perempuan lajang bukan lagi sebuah predikat yang patut ditutupi, tapi juga dikaitkan dengan sukses mengejar karier dan tujuan hidup yang semakin beragam.

Diantara berbagai media massa yang ada, majalah perempuan merupakan media yang dekat dengan perempuan. Di Indonesia sendiri terdapat berbagai macam majalah perempuan, menjangkau berbagai segmen mulai dari kaum remaja (Gadis, Aneka, Seventeen, Cosmopolitan Girl, dan lain-lain), hingga 
perempuan dewasa (Femina, Cosmopolitan, Kartini, Cita Cinta, Cleo, Dewi, Elle dan lain-lain).

\section{MAJALAH PEREMPUAN}

Majalah adalah suatu publikasi yang diterbitkan secara berkala, berisi berbagai artikel, serta secara umum dibiayai oleh halaman iklan yang dijual maupun dari pembelian eksemplar majalah tersebut oleh pembacanya (Harjanto, 2009: 414). Sedangkan menurut Junaedhie (1995: xiii), majalah adalah:

1. Media cetak yang terbit secara berkala, tapi bukan yang terbit setiap hari

2. Media cetak yang memiliki sampul, setidak-tidaknya punya wajah dan dirancang secara khusus

3. Media cetak itu dijilid atau sekurang-kurangnya memiliki sejumlah halaman tertentu

4. Media cetak itu, harus berformat tabloid, atau saku, atau format konvensional sebagaimana format majalah yang kita kenal selama ini

Majalah modern yang massal, murah dan memenuhi selera banyak orang, merupakan hasil dari kemajuan teknologi. Kecepatan mesin produksi dan transportasi memungkinkan majalah menjadi media nasional yang bisa dibuat dan disebarkan ke berbagai wilayah secara cepat (Rivers, Jersen, Peterson, 2008: 56).

Menurut Kasali (1992: 108), setiap majalah umumnya mempunyai pembaca yang jauh lebih sedikit daripada pembaca surat kabar, namun memiliki pasar yang lebih mengelompok. Majalah memiliki kedalaman isi yang jauh berbeda dengan surat kabar yang hanya menyajikan berita. Disamping itu, majalah menemani pembaca dengan menyajikan cerita atau berbagai kejadian dengan tekanan pada unsur menghibur atau mendidik.

Di abad ke-19, ketika majalah hanya diperuntukkan bagi kalangan terbatas (umumnya kaum elite), pengasuhnya bisa memilih artikel apa saja yang dianggapnya sesuai. Namun sekarang, pengasuh majalah harus mengakomodir minat pembaca, sehingga ia tidak leluasa memilih menurut penilaiannya sendiri. Karakter majalah pun harus didasarkan pada selera pasar (Rivers, Jersen, Peterson, 2008: 73).

Ibrahim (1998: 126) berpendapat bahwa fungsi majalah jauh melebihi bacaan biasa. Fungsi-fungsi itu antara lain:

1. Memberi informasi tentang kejadian-kejadian di dunia, yang aktual maupun yang tidak aktual tetapi mengesankan

2. Memberi informasi tentang mode, masakan dan sebagainya 
3. Majalah dapat memberikan konsultasi mengenai kesehatan, kecantikan, menu masakan dan pertanyaan-pertanyaan lain yang penting atau yang sewaktuwaktu berguna

4. Melalui rubrik-rubrik khusus yang disediakan, pembaca dapat mengadakan konsultasi tentang masalah pribadinya, tanpa diketahui identitasnya. Serta dengan membacanya tentang masalah-masalah yang diajukan orang lain, ia dapat menafsir masalahnya sendiri, dan sering dapat menemukan jawaban dengan berpikir tentang masalah orang lain

Menurut Harjanto (2009: 415), majalah dapat dikategorikan ke dalam dua golongan, yaitu majalah bidang umum seperti Tempo, Gatra, Trust, dll, dan majalah bidang khusus seperti majalah perempuan (Femina, Kartini, dll), majalah bisnis (SWA, Marketing, dll), majalah otomotif (Autocar, dll), majalah pria (Matra, Men's Health, dll), dan majalah IT (CHIP, Info Komputer, dll).

Sebagai salah satu media massa, majalah memiliki kekuatan dan kelemahan diantaranya:

Table 1: Kekuatan dan Kelemahan Majalah

\begin{tabular}{|c|c|}
\hline Kekuatan Majalah & Kelemahan Majalah \\
\hline $\begin{array}{l}\text { Selektifitas Khalayak. Khalayak } \\
\text { majalah secara alami adalah sekelompok } \\
\text { orang yang memiliki karakter dan minat } \\
\text { yang sama. Khalayak majalah seringkali } \\
\text { memiliki ikatan emosional dengan } \\
\text { majalah-majalah kesayangan mereka }\end{array}$ & $\begin{array}{l}\text { Tenggang Waktu yang Panjang. } \\
\text { Penyiapan untuk proses pencetakan } \\
\text { samapai waktu edar majalah } \\
\text { memerlukan waktu yang cukup } \\
\text { panjang }\end{array}$ \\
\hline $\begin{array}{l}\text { Daur Hidupnya Panjang. Meskipun isi } \\
\text { majalah merupakan kumpulan dari } \\
\text { informasi terkini, tetapi informasi } \\
\text { tersebut seringkali dapat digunakan } \\
\text { melampaui batas waktunya, karena } \\
\text { informasi tersebut seringkali disimpan } \\
\text { oleh khalayaknya sebagai bahan } \\
\text { referensi }\end{array}$ & $\begin{array}{l}\text { Keterbatasan Pola Sirkulasi. Karena } \\
\text { segmentasi pembaca maupun wilayah } \\
\text { edarnya, majalah memiliki } \\
\text { keterbatasan pola sirkulasi. }\end{array}$ \\
\hline $\begin{array}{l}\text { Kualitas Produksi Baik. Majalah adalah } \\
\text { media yang diproduksi dengan mutu } \\
\text { cetak berkualitas tinggi, sehingga } \\
\text { mampu menampilkan produksi gambar } \\
\text { yang baik, indah, istimewa, bergengsi, } \\
\text { dan memiliki daya tarik kemewahan }\end{array}$ & \\
\hline
\end{tabular}


\begin{tabular}{|l|l|}
\hline Sumber Referensi. Majalah memiliki & \\
kemampuan untuk memberikan & \\
informasi secara rinci, sehingga dapat & \\
berfungsi sebagai sumber yang sangat & \\
baik untuk dijadikan referensi bagi para & \\
pembacanya. Terutama karena editorial & \\
majalah seringkali menyajikan artikel- & \\
artikel yang menunjukkan wawasan, & \\
keahlian dan kredibilitas & \\
\hline
\end{tabular}

Sumber Harjanto, 2009: 415-417

Menurut Sidharta (1998:126), majalah perempuan adalah majalah yang mempunyai fungsi khusus, yaitu menciptakan dunia khas bagi kaum perempuan. Ia juga mengemukakan ada empat fungsi majalah perempuan, yaitu:

a. Memberi informasi tentang kejadian-kejadian di dunia yang aktual, maupun yang tidak aktual tetapi mengesankan.

b. Memberi informasi tentang mode, masakan dan sebagainya dan melalui iklan-iklannya juga komoditi-komoditi yang berguna atau yang sewaktuwaktu akan berguna.

c. Ia dapat dikonsultasi sewaktu-waktu mengenai kesehatan, kecantikan, menu masakan dan lain-lain pertanyaan yang penting atau yang akan menjadi penting.

d. Melalui rubrik-rubrik khusus yang disediakan, pembaca dapat mengadakan konsultasi tentang masalah pribadinya, tanpa diketahui identitasnya. Dan dengan membaca tentang masalah-masalah yang diajukan oleh orang lain, ia dapat menafsirkan masalahnya sendiri, sering ia dapat menemukan jawaban dengan berpikir tentang masah orang lain.

Storey (2007:105) mengutip pendapat Janice Winship menulis bahwa menghilangkan majalah peremuan berarti menghilangkan kehidupan jutaan perempuan yang membaca dan menikmatinya setiap minggu. Hal ini terkait dengan beberapa tugas majalah perempuan seperti dikemukakan oleh Sidharta (1998: 127):

1. Memperbaiki gaya hidup perempuan, dari gaya hidup pasif-konsumtif menjadi gaya hidup aktif-kreatif

2. Meningkatkan selera pembaca, dari bacaan penghibur dan sensasional provokatif menjadi bahan bacaan berpikir dan berarti

3. Mendidik kaum perempuan menjadi perempuan yang mengetahui hak-hak dan batas-batas kewajibannya di dunia yang didominasi kaum pria

4. Mendidik kaum perempuan untuk menghadapi tugas-tugas dan masalahmasalah di kemudian hari 
Sejak lahirnya pada akhir abad ke - 18, majalah-majalah untuk perempuan telah menawarkan pembacanya sebuah perpaduan antara saran dan hiburan. Tanpa menghiraukan politik, majalah perempuan terus beroperasi sebagai buku pedoman kelangsungan hidup, yang membekali para pembacanya dengan saran praktis dan bagaimana hidup dalam budaya patriarkal (Storey, 2007:105).

Di Indonesia, beberapa penerbitan khusus perempuan muncul pada awal 1970-an, antara lain: Femina (1972), Kartini (1973), Pertiwi (1986) dan Sarinah (1986). Bisnis majalah perempuan di Indonesia mengalami perkembangan pesat. Pada tahun 1990-an banyak majalah perempuan yang penampilan artistik-visual tak kalah canggih dari majalah perempuan di Barat yang memang menjadi acuan majalah perempuan di Indonesia (Ibrahim, 1998: 94 \& 112).

Sejarah perkembangan majalah perempuan di Indonesia dirangkum oleh Junaedhie (1995: 69-89):

1906: Majalah perempuan pertama di Indonesia terbit dengan nama Tiong Hwa Wi Sien Po, yang diasuh oleh Lien Titie Nio

1908: Terbit majalah perempuan kedua yang diberinama Poeteri Hindia, dipimpin oleh RTA Tirtokoesoemo

1912: Dari Sumatera Barat muncul majalah perempuan Soenting Melajoe, dibawah pimpinan Datoe Soetan Maharadja

1918 : Di Solo terbit majalah perempuan yang diberinama Hesti Oetama, yang menggunakan bahasa Jawa

1919: Tanggal 15 Mei 1919, di Sumatera muncul majalah perempuan bernama Perempoean Bergerak, yang diterbitkan oleh Parada Harahap

1922: Terbit majalah perempuan Doenia Isteri, dibawah asuhan Siti Danilah dan Rebecca

1924: Pada bulan April 1924, muncul majalah perempuan yang menggunakan bahasa Melayu, dan diberi nama Istri Soesilo, dengan misi pendidikan dikalangan perempuan

1930 : Terbit majalah bernama Fu Len (artinya istri) yang diterbitkan oleh Ny. Tjoa Hin Hoey

1938 : Dari Medan terbit majalah perempuan Doenia Kita, dengan pendirinya Ny. Siti Alimah Latip

1949: Ny. Ani Idrus di Medan menerbitkan majalah perempuan Doenia Wanita

1972 : Pada tanggal 18 September 1972, PT. Gaya Favorit Press pimpinan Sofyan Alisjahbana, menerbitkan majalah perempuan yang diberinama Femina

1973 : Terbit majalah perempuan Ideal dari kelompok penerbit Selecta 
1974: Pada bulan November 1974, terbit majalah perempuan Kartini, yang disusul dengan terbitnya majalah Contessa pada 7 Desember 1974 yang diterbitkan oleh Yayasan Tetap Teguh

1977: Yayasan Tri Karya Press menerbitkan majalah perempuan dengan nama Shinta

1980 : Pada bulan September 1980, Titie dan Lies Said menerbitkan majalah perempuan bernama Famili

1982 : Terbit majalah Tata Rias, yang mengklaim sebagai majalah perempuan bulanan yang menyajikan masalah khusus rambut dan kecantikan. Pada bulan September 1982, terbit majalah Sarinah dibawah asuhan Lukman Umar

1983 : Terbit majalah Intan, yang menyajikan masalah khusus fashion, rambut dan kecantikan

1984 : Kelompok penerbit Femina mencoba membuat kejutan baru dengan menerbitkan majalah Dewi, dengan sasaran pembaca kalangan perempuan aktif

1986: Pada tanggal 5 Mei 1986, Yayasan Gema Nawa Pratasa menerbitkan majalah perempuan Pertiwi. Di Surabaya, terbit majalah perempuan dengan nama Liberty, yang mengklaim dirinya sebagai satu-satunya majalah perempuan di Jawa Timur

1987 : Terbit majalah Mahkota, yang menyoroti dunia perkawinan

1991: Kelompok Femina menerbitkan lagi majalah perempuan bernama Dewi, yang mengutamakan pemberitaan dan informasi mengenai dunia mode dengan gaya kosmopolitan

\section{FEMINISME}

Definisi umum dari feminisme adalah kesadaran akan penindasan dan pemerasan terhadap kaum perempuan dalam masyarakat, di tempat kerja dan dalam keluarga, serta tindakan sadar oleh perempuan maupun lelaki untuk mengubah keadaan tersebut. (Bhasin dan Khan, 1999: 5). Sedangkan menurut Naomi Wolf seperti dikutip oleh Kasiyan $(2008,74)$ feminisme adalah sebuah teori yang mengisahkan harga diri pribadi dan harga diri seluruh kaum perempuan. Oleh karena itu, "menjadi feminis" diartikan "menjadi manusia".

Feminisme harus dipahami secara luas sebagai gerakan kemanusiaan demi keadilan sosial. Menurut Bhasin dan Khan (1999: 8), pada hakikatnya feminisme adalah perjuangan untuk mencapai kesederajatan/kesetaraan, harkat, serta kebebasan perempuan untuk memilih dalam mengelola kehidupan dan tubuhnya, baik di dalam maupun di luar rumah tangga. 
Gerakan feminisme dapat dibagi dalam tiga gelombang. Gerakan feminisme awal yang dimulai sejak 1800an merupakan landasan awal dari gerakan perempuan (Arivia, 2003: 84). Konvensi di Seneca Falls pada tahun 1848 dianggap sebagai awal gerakan feminisme dengan semboyan "All men and woman are created equal". Tujuan gerakan feminisme untuk meningkatkan kedudukan dan derajat perempuan agar sama atau sejajar dengan kedudukan serta derajat laki-laki (Djajanegara, 2003: 1-10).

Gelombang kedua gerakan feminisme ditandai dengan terbitnya buku The Feminine Mystique di Amerika 1963. Tuntutan yang dikemukakan masih sama dengan gelombang pertama. Namun untuk memperkuat tuntutan tersebut, mereka juga memperjuangkan masalah-masalah lain seperti seksualitas perempuan, hak untuk menguasai tubuh sendiri, anti pelecehan seksual, penghapusan diskriminasi seksual disegala bidang, serta pembagian pekerjaan rumah tangga secara adil (Djajanegara, 2003:1-10). Pada gelombang kedua, gerakan perempuan mempertanyakan representasi gambaran perempuan dan segala sesuatu yang feminin, serta muncul refleksi tentang persoalan-persoalan perempuan, dan sebagai turunannya lahir teori-teori yang menyusun mengenai kesetaraan perempuan (Arivia, 2003: 84).

Pada gelombang ketiga, teori-teori yang muncul lebih plural, mengikuti dan bersinggungan dengan pemikiran-pemikiran kontemporer (Arivia, 2003: 84). Gerakan geminisme pada gelombang ketiga sangat dipengaruhi oleh pemikiran postmodernisme yang memfokuskan diri pada wacana alternatif dan melihat kembali apa yang telah dibuang, dilupakan, dianggap irasional, tidak penting, tradisional, ditolak dan semua yang tidak pernah diperhatikan oleh pemikiran modernisme (Arivia, 2003: 127).

Jenis gerakan feminisme yang ada di dunia menurut Kasiyan $(2008,85)$ cukup banyak; masing-masing memiliki karakteristik yang berbeda. Hal ini disebabkan oleh perbedaan asumsi dasar dan paradigma dalam memandang akarakar persoalan, yang berakibat ketimpangan gender antara laki-laki dan perempuan di masyarakat. Secara garis besar, arus utama gerakan feminisme tersebut dikelompokkan menjadi dua kategori besar. Pertama, gerakan yang diilhami oleh paradigma fungsionalisme struktural, yakni Feminisme Liberal. Kedua, gerakan yang dipengaruhi oleh paradigma konflik, yakni Feminisme Radikal, Feminisme Sosialis dan Feminisme Marxis.

Gerakan feminisme mengenal beberapa teori yang mewakili setiap gelombang gerakan feminisme, diantaranya:

\section{Table 2: Teori Feminisme}

\begin{tabular}{|c|c|c|c|}
\hline Gelombang & Feminisme & Dasar Pemikiran & Isu-Isu Feminis \\
\hline Pertama & $\begin{array}{l}\text { Feminisme } \\
\text { Liberal }\end{array}$ & $\begin{array}{l}\text { Manusia adalah otonom } \\
\text { dan dipimpin oleh akal. } \\
\text { Dengan akal manusia }\end{array}$ & $\begin{array}{l}\text { Akses pendidikan. } \\
\text { Kebijakan negara yang } \\
\text { bias gender. }\end{array}$ \\
\hline
\end{tabular}




\begin{tabular}{|c|c|c|c|}
\hline & & $\begin{array}{l}\text { mampu untuk memahami } \\
\text { prinsip-prinsip moralitas, } \\
\text { kebebasan individu. } \\
\text { Prinsip-prinsip ini juga } \\
\text { menjamin hak-hak } \\
\text { individu }\end{array}$ & Hak-hak sipil, politik. \\
\hline & $\begin{array}{l}\text { Feminisme } \\
\text { Radikal }\end{array}$ & $\begin{array}{l}\text { Sistem seks/gender } \\
\text { merupakan dasar } \\
\text { penindasan terhadap } \\
\text { perempuan }\end{array}$ & $\begin{array}{l}\text { Adanya seksisme, } \\
\text { masyarakat patriarki. } \\
\text { Hak-hak reproduksi. } \\
\text { Hubungan kekuasaan } \\
\text { antara perempuan dan } \\
\text { laki-laki. } \\
\text { Dikotomi } \\
\text { private/public. } \\
\text { Lesbianisme }\end{array}$ \\
\hline & $\begin{array}{l}\text { Feminisme } \\
\text { Marxis }\end{array}$ & $\begin{array}{l}\text { Materialisme Historis } \\
\text { Marx yang mengatakan } \\
\text { bahwa "Modus produksi } \\
\text { kehidupan material } \\
\text { mengkondisikan proses } \\
\text { umum kehidupan sosial, } \\
\text { politik dan intelektual. } \\
\text { Bukan kesadaran yang } \\
\text { menentukan eksistensi } \\
\text { seseorang tetapi eksistensi } \\
\text { sosial mereka yang } \\
\text { menentukan kesadaran } \\
\text { mereka". }\end{array}$ & $\begin{array}{l}\text { Ketimpangan } \\
\text { ekonomi. } \\
\text { Kepemilikan properti. } \\
\text { Keluarga dan } \\
\text { kehidupan domestik } \\
\text { di bawah kapitalisme. } \\
\text { Kampanye } \\
\text { pengupahan kerja } \\
\text { domestik. }\end{array}$ \\
\hline Kedua & \begin{tabular}{|l|} 
Feminisme \\
Psikoanalisis
\end{tabular} & $\begin{array}{l}\text { Penjelasan mendasar } \\
\text { penindasan perempuan } \\
\text { terletak pada } p s y c h e \\
\text { perempuan, cara } \\
\text { perempuan berpikir. }\end{array}$ & $\begin{array}{l}\text { Egosentrisme laki-laki } \\
\text { yang menganggap } \\
\text { perempuan menderita } \\
\text { "penis envy". } \\
\text { Reinterpretasi } \\
\text { Oedipus kompleks. } \\
\text { Dual parenting } \\
\text { Feminisme gender- } \\
\text { etika perempuan. }\end{array}$ \\
\hline Ketiga & \begin{tabular}{|l|} 
Feminisme \\
Postmodern
\end{tabular} & $\begin{array}{l}\text { Seperti alisan filsafat } \\
\text { postmodernisme menolak } \\
\text { pemikiran phallogosentris } \\
\text { (ide-ide yang dikuasai } \\
\text { oleh logos absolut yakni } \\
\text { "laki-laki" - bereferensi } \\
\text { pada phallus) }\end{array}$ & $\begin{array}{l}\text { 'Otherness" dari } \\
\text { perempuan yang } \\
\text { dilontarkan oleh } \\
\text { Simone de Beauvoir, } \\
\text { merupakan sesuatu } \\
\text { yang lebih dari kondisi } \\
\text { inferioritas dan }\end{array}$ \\
\hline
\end{tabular}




\begin{tabular}{|l|l|l|}
\hline & $\begin{array}{l}\text { ketertindasan tetapi } \\
\text { juga merupakan cara } \\
\text { berada, cara berpikir, } \\
\text { berbicara, } \\
\text { keterbukaan, pluraitas, } \\
\text { diversitas dan } \\
\text { perbedaan. }\end{array}$ \\
\hline
\end{tabular}

Sumber Arivia, 2003: 152-153

Feminisme liberal merupakan gerakan perjuangan kesetaraan gender yang usianya paling tua. Kaum feminisme liberal mendasari gerakkannya pada prinsipprinsip falsafah liberalisme, yakni semua orang diciptakan dengan hak-hak yang sama dan setiap orang harus mempunyai kesempatan yang sama untuk memajukan dirinya. (Kasiyan. 2008: 86)

Feminisme radikal beranggapan faktor utama yang menjadi sebab pembagian kerja secara seksual adalah sistem patriarkal (Kasiyan. 2008: 88). Tokoh feminisme radikal adalah Foucault, Derrida, Lyotard. Ketiganya dikenal pula sebagai tokoh posmo. Feminisme radikal menekankan bahwa perempuan mampu bekerja di bidang apapun sebagaimana laki-laki dan juga berhak untuk memilih hidup heteroseksual atau homoseksual (Muhadjir, 2002: 323).

Gerakan feminisme Marxis menekankan bahwa ketidakadilan gender dalam masyarakat lebih disebabkan oleh penindasan kelas dalam hubungan produksi ekonomi. Oleh karena itu persoalan penindasan perempuan selalu diletakkan dalam kerangka kritik terhadap kapitalisme. Bagi feminisme Marxis, penindasan perempuan merupakan kelanjutan dari sistem eksploitatif yang bersifat struktural. Mereka tidak menganggap sistem patriarki sebagai permasalahan, akan tetapi sistem kapitalisme yang menjadi penyebabnya. (Kasiyan. 2008: 91)

Feminis psikoanalisis menguraikan pentingnya perempuan mengungkapkan persoalan-persoalan seksualitas karena kesetaraan terhadap perempuan dianggap hanya dapat dilakukan lewat pembebasan seksual. Karena pembahasan-pembahasan tubuh dan seksualitas perempuan dianggap penting, oleh sebab itu seringkali perempuan diasingkan dari tubuh dan seksualitasnya. Feminis psikoanalisis menganggap eksplorasi psyche (jiwa, hati) perempuan menjadi penting (Arivia, 2006: 54).

Postmodernisme mengatakan bahwa seluruh realitas terdiri dari teks. Maka pengetahuan tentang perempuan maupun laki-laki adalah tekstual. Dengan demikian, kontribusi terbesar pemikiran feminisme postmodernisme adalah dekonstruksi teks-teks bias gender. Feminis Postmodern menganggap masyarakat hanya dilengkapi oleh bahasa laki-laki karena masyarakat yang kita hidup ini menggunakan aturan-aturan simbolis yang berpusat pada laki-laki (Arivia, 2006: 20-55). 
Dalam penelitian ini, teori feminisme yang akan digunakan adalah feminisme liberal, karena feminisme liberal merupakan gerakan pertama dari perjuangan perempuan dan memiliki pemikiran yang sering digunakan dalam setiap gerakan perempuan dari awal sampai saat ini. Teori feminisme liberal juga mengangkat isu-isu yang sering menjadi pembahasan dan merupakan dasar dari perjuangan kaum perempuan.

\section{PENUTUP}

Perempuan dan media, terutama majalah perempuan merupakan dua hal yang sulit dipisahkan. Majalah perempuan yang saat ini banyak beredar di Indonesia merupakan cerminan dari kehidupan perempuan Indonesia secara umum. Perempuan tidak lagi diposisikan selalu lemah dan hanya berkiprah seputar ranjang dan dapur, namun perempuan Indonesia mulai dilihat sebagai pribadi-pribadi yang mampu berkiprah dalam dunia kerja dan bersaing dengan kaum laki-laki.

Majalah perempuan yang beredar di Indonesia saat ini mengandung nilainilai feminisme yang sangat kuat. Hal ini terlihat dari perkembangan dari awal majalah perempuan muncul di Indonesia tahun 1906 sampai saat ini. Isu kesetaraan gender dan perlakuan yang sama antara perempuan dan laki-laki sering diangkat dalam setiap edisi majalah. Persamaan perlakuan tersebut tidak hanya di dunia pekerjaan, namun juga di dunia pendidikan. Jika kita melihat lebih cermat, bahkan saat ini banyak majalah perempuan yang mengangkat isu feminis yang menekannya kepada kemandirian perempuan yang mampu berdiri sendiri tanpa laki-laki. Secara tersirat bahkan tidak jarang dalam penyajiannya, majalah perempuan menggambarakan perempuan mandiri yang bahagia dengan tidak terikat dalam lembaga perkawinan.

Nilai-nilai feminisme yang ada dalam penyajian setiap majalah perempuan, mampu membuka mata perempuan Indonesia untuk merubah hidupnya menjadi lebih maju. Hal ini terlihat dari semakin banyaknya perempuan Indonesia yang bisa meraih pendidikan tinggi dan juga posisi-posisi penting dalam dunia kerja. Perempuan tidak lagi dipandang sebelah mata dan mulai diakui keberadaannya sebagai individu yang layak disejajarkan dengan kaum lakilaki. Namun demikian, majalah perempuan di Indonesia tidak semuanya berani secara terang-terangan mengangkat isu persamaan gender, dalam penyajiannya majalah perempuan Indonesia tetap memasukkan unsur budaya timur dan mengingatkan kaum perempuan akan kodratnya sebagai perempuan yang apabila telah menikah maka dia harus patuh teradap suaminya. Pada ranah ini, sering kali terjadi persinggungan antara nilai-nilai feminisme dan juga nilai-nilai sosial budaya Indonesia. Namun demikian, dengan semakin majunya tingkat pendidikan dan semakin berkembangnya cara berpikir, perempuan Indonesia dapat memilih mana yang sesuai bagi dirinya dan bisa menentukan tujuan hidupnya sendiri. 


\section{Daftar Pustaka}

Arivia, Gadis. 2003. Filsafat Berperspektif Feminis. Jakarta: Yayasan Jurnal Perempuan

Armando, Ade, Gadis Arivia, Maria Hartiningsi, dkk. 2004. Telaah Kritis Potret Perempuan Di Media Massa. Jakarta: PT. Primamedia Pustaka.

Berger, Arthur Asa. 2000. Media Analysis Techniques. Yogyakarta: Universitas Atmajaya Yogyakarta.

Bhasin, Kamla dan Nighat Said Khan. 1999. Persoalan Pokok Mengenai Feminisme dan Relevansinya. Jakarta: Gramedia Pustaka Utama

Djajanegara, Soenarjati. 2003. Kritik Sastra Feminis: Sebuah Pengantar. Jakarta: PT. Gramedia Ustaka Utama

Dwiputri, Agustine. “Perempuan Lajang”. Jakarta: Kompas, Minggu 12 Oktober

Fakih, Mansour. 2008. Analisis Gender dan Transformasi Sosial. Yogyakarta: INSIST Press

Fatimah. Femina, No.14/XXXVII.4-10 April 2009

Harjanto, Rudi. 2009. Prinsip-Prinsip Periklanan. Jakarta: Dewan Perguruan Periklanan Indonesia

Ibrahim, Idi Subandy, Hanif Suranto, Ade Armando, Akhmad Zaini Abar, eds. 1998. Wanita dan Media: Konstruksi Ideologi Gender Dalam Ruang Publik Orde Baru. Bandung: PT. Remaja Rosdakarya

Ibrahim, Linda. Femina, No.12/XXXVII.21-27 Maret 2009

Jamhari \& Ismatu Ropi. 2003. Citra Perempuan dalam Islam: Pandangan Ormas Keagamaan. Jakarta: PT. Gramedia Pustaka Utama

Junaedhie, Kurniawan. 1995. Rahasia Dapur Majalah di Indonesia. Jakarta: PT. Gramedia Pustaka Utama

Kartika. Memikirkan Perkawinan. Jakarta: Jurnal Perempuan No. 22, 2002

Kasali, Rhenald. 2005. Membidik Pasar Indonesia: Segmentasi, Targeting, Positioning. Jakarta: PT. Gramedia Pustaka Utama

Kasiyan. 2008. Manipulasi dan Dehumanisasi Perempuan dalam Iklan. Yogyakarta: Ombak

Lie, Shirley. 2005. Pembebasan Tubuh Perempuan. Jakarta: PT. Grasindo

Muhadjir, Noeng. 2002. Metodologi Penelitian Kualitatif: Edisi IV. Yogyakarta: Rake Sarasin

Naqiyah, Najlah. 2005. Otonomi Perempuan. Malang: Banyumedia Publishing 
Ollenburger, Jane C \& Helen A. Moore. 2002. Sosiologi Wanita. Jakarta: PT. Rineka Cipta

Rivers, William L, Jay W. Jensen, Theodore Peterson. 2008. Media Massa dan Masyarakat Modern. Jakarta: Kencana

Sastriyani, Siti Hariti. 2008. Woman in Public Sector. Yogyakarta: Tiara Wacana (Kerjasama Pusa Kajian Wanita UGM)

Savitri. Femina No.12/XXXVII.21-27 Maret 2009

Storey, John. 2007. Cultural Studies dan Kajian Budaya Pop. Yogyakarta: Jalasutra

Sunarto. 2000. Analisis Wacana Ideologi Gender Media Anak-Anak. Semarang: Penerbit Mimbar

Sushartami, Wiwik. Perempuan Lajang: Meretas Identitas di Luar Ikatan Perkawinan. Jakarta: Jurnal Perempuan no. 22, 2002

Verdiansyah, Chris. 2007. Sukses dalam Karier dan Rumah Tangga. Jakarta: PT. Kompas Media Nusantara 